\title{
Water Quality Monitoring in Inle Lake, Myanmar from the Floating Garden Activity
}

\author{
Theingi Khaung, Chuleemas Boonthai Iwai*, Thammared Chuasavathi \\ Department of Soil Science and Environment, Faculty of Agriculture, Khon Kaen \\ University, Thailand
}

Abstract Inle Lake is the second largest inland lake in Myanmar. Floating gardens, mostly for tomato cultivation, are a unique and profitable method of agriculture used by people living on and around the lake. This study investigated the water quality of Inle Lake and how it has been affected by the different agricultural practices used in tomato cultivation on floating garden beds, by measuring pollution levels. Water samples were collected from the sites representing two types of agricultural practice from four villages. The first was designated as being grown under good agricultural practices (GAP), and the other as under non-good agricultural practices (non-GAP), with this study undertaken during wet season, 2019 and dry season, 2020. Two additional sets of water samples were collected as references. One of these sets was from the center of the lake and the other from an inlet stream to the lake. All water samples were analyzed for physical and chemical properties. The results found that $\mathrm{Ca}^{2+}, \mathrm{Mg}^{2+}$ and $\mathrm{HCO}_{3}{ }^{-}$were dominant in the lake surface water. The results showed significant differences in the mean values for some water quality parameters between the GAP and non-GAP of each study sites in both seasons. In particular, nutrient pollution from chemicals such as nitrogen and phosphorus from the non-GAP were significantly higher than those from GAP. Water quality index was calculated to describe the overall quality of lake surface water. It was observed that the water quality was almost threatened in the floating garden areas. In comparison between two practices, the non-GAP gave the higher water quality index value than the GAP. This investigated that poor management of fertilizers usage has had a negative effect on the water quality of the lake. The differences seen in water quality from the GAP and non-GAP areas, point to ways to successfully manage sources of water pollution in order to better conserve the lake by sustainable agricultural production.

Keywords: Water monitoring, fertilizers, water pollution, water quality index

*For correspondence: chulee_b@kku.ac.th

Received: 13 July 2021 Accepted: 11 October 2021

(C) Copyright Khaung. This article is distributed under the terms of the Creative Commons Attribution License, which permits unrestricted use and redistribution provided that the original author and source are credited.

\section{Introduction}

Wetland is a unique ecosystem derived by the interaction of water and land, which provide ecological goods and services but many wetlands are exposed to anthropogenic pressures, land use patterns change in catchment, and over exploitation of natural sources enhance the degradation of wetlands ecosystem [1]. Southeast Asia contains a major portion of world's wetlands area in significant of the international wetlands, but only $14 \%$ of these wetlands include under production [2]. Lakes, an important feature of the Earth's landscape, are not only the source of precious water, but provide valuable habitats to plants and animals, [3]. Inle Lake is the second largest inland wetland in Myanmar and the most essential for its environmental, social and agricultural activities. In 1985, the Inle Wetland Wildlife Sanctuary (IWWS) composing of $700 \mathrm{~km}^{2}$ and it is a noticeable water support for the greatest hydropower generation and the most famous ecotourism sites because of its unique lifestyles and traditions, hydroponic nature of floating garden (prepared by using aquatic weeds and bottom silt) agriculture. Akaishi et al. [4] studied that tomato constitute about two-thirds of the Inle region's agriculture, is the 
main business for farmers and about $75 \%$ of the product is transported to the markets throughout the country. Khurtsia [5] observed that tomato production became the biggest in Inle Lake and consumed the chemical fertilizers to boost yields. The excessive use of fertilizers in many intensive farming systems observed that it disturbs the mitigation of water pollution from agriculture [6], causes greenhouse gas emission and long term pollution of soils [7].

Inle lake has been suffering both threads exactly natural and anthropogenic activities, which caused degradation of water quality, [8]. Su and Jassby [9] observed that the Inle lake water quality was decreased by floating islands, shifting cultivation, village expansion and resulted in contamination of lake. Akaishi et al. [4] studied that some physical and chemical aspects of the surface water in natural and cultural environments, indicated that $\mathrm{Ca}^{2+}$ and $\mathrm{HCO}_{3}{ }^{-}$are the main ion species in lake water, the trophic state is eutrophic and $\mathrm{PO}_{4}-\mathrm{P}, \mathrm{NO}_{2}-\mathrm{N}$, and $\mathrm{NO}_{3}-\mathrm{N}$ were relatively high; these could originate from household and agriculture uses. The water quality assessment in 2012 for lake conservation activity indicates that there is deterioration of the lake water quality due to anthropogenic activities [3]. More recently, Pradhan et al. [10] conducted, with an emphasis on water quality from the entire Inle lake surface area. It was observed that various environmental impacts are affecting the lake ecosystem; among them pollution from floating gardens agriculture had the most critical impacts and they concluded that decreasing dissolved oxygen related to nutrients leaching out of the floating gardens.

The conventional agriculture, non-good agricultural practices (non-GAP) has caused economic problems and ecological problems but integrated agricultural production systems alleviate these economic and ecological problems as lower input of fertilizers, pesticides. In Myanmar, the good agricultural practice (GAP) for tomato production in Inle Lake was initiated in 2017 and is a governmental initiative to promote sustainable practices and improve the ecosystem's sustainability. GAP-practicing farmers are able to produce high quality tomatoes but most of the farmers cultivate by non-GAP that increase negative impacts on the environment, including higher fertilizer and pesticide application, have more widespread [11]. GAP program increases input use efficiency and reduce their negative impacts on the environment, including improving the efficiency of fertilizer and pesticide applications [12]. The deterioration of water quality is associated with tomato production on floating garden in Inle lake and thus, the water quality monitoring is essential to assess water pollution.

Water quality index (WQI) method is a simple and concise method for the expression of surface water quality by using single numbers. However, there is no work on available WQI to assess the water quality status in GAP and non-GAP tomato production on floating garden. Therefore, this study examines water quality index as affected by GAP and non-GAP of tomato production throughout the seasonal analysis to characterize the fluctuations in water quality of lake. The present study is devoted to the implement of good agricultural practices in Inle Lake and to sustain the agricultural production, because of the utmost importance to the ecosystem's sustainability. The objective of this study was to compare water quality in GAP and non-GAP tomato cultivation by evaluating water quality index for the two seasons. The goal of this study is to provide the current information for aquatic ecologists and acquaint researchers about water body in GAP and non-GAP floating gardens and farmers' awareness for sustainable agriculture production with reduce negative impact on environments.

\section{Materials and methods}

\section{Study area}

The study area is situated in the floating gardens of Inle Lake, Nyaung Shwe Township, Southern Shan state, Myanmar. Geographical coordinates are $20^{\circ} 15^{\prime}$ to $20^{\circ} 45^{\prime} \mathrm{N}$ latitude and $96^{\circ} 49^{\prime}$ to $96^{\circ} 48^{\prime} \mathrm{E}$ longitude, with an elevation of $890 \mathrm{~m}$ a.s.I [9]. Most recently, Myanmar census reported that Nyaung Shwe Township comprises eight wards and 35 village tracts (446 villages) with a population of 189,407 [13], but only 22 village tracts (136 villages) in the lake area [11]. Recently, the lake has about $17.5 \mathrm{~km}$ long and $5 \mathrm{~km}$ width with average open water depth of about $1 \mathrm{~m}$ in dry season (April 2015-2016) and average depth of about 2.2-2.5m in rainy season (October 2015-2016) and resulted that $3.18 \mathrm{~m}$ is the maximum lake open water depth by bathymetric survey [14]. Su and Jassby [9] observed 30 streams are flowing to the lake: of 
which 17 from the east, 12 from the west. One from the north, the major inflow stream (Nanlit Chaung) which flows by Nyaung Shwe town, far about $2 \mathrm{~km}$ from north of the lake and the only outlet stream is in the south and leadings into the Thanlwin river. Estimated watershed area of lake has $5612 \mathrm{~km}^{2}$ with an average annual inflow water volume of $1.1 \times 10^{8} \mathrm{~m}^{3}$ per year, and water residence of 0.32 years with maximum water storage capacity of $3.5 \times 10^{7} \mathrm{~m}^{3}$ [9]. The climate of lake area includes in humid subtropic (Cwa according to the Köppen-Geiger classification) with three seasons: summer (dry) season starts from March and ends at June, rainy (wet) season from July to October and winter (cold) season from November to February. The area of Lake bio-zone is $116 \mathrm{~km}^{2}$ with the water body making up an area of $59 \mathrm{~km}^{2}$. There are 2448 hectares $\left(24.48 \mathrm{~km}^{2}\right)$ of floating garden for tomato production in 201819 and within this area 182 hectares (about 7.5\%) has been assessed as being farmed according to good agricultural practices [11].

Prior to field sampling and testing, the study sites were assessed to identify for monitoring water quality. A field survey was completed to identify four sampling sites. The four villages selected were; Village-1: Kyaesargone (northern part); Village-2: Kaylar (middle part); Village-3: Ngaphaechaung (middle part); Village-4: Zayatgyi (southern part) of the lake (Figure 1). In each village, two types of agricultural practice, GAP and non-GAP, were identified and sampled in order to investigate the effects on the water quality as a result of these farming methods. Two additional sets of water samples were collected as references. One of these sets was from the centre of the lake and the other from an inlet stream to the lake (Table 1).

Table 1. Information for the study sites in Inle Lake

\begin{tabular}{llrl}
\hline Site $(\mathrm{S})$ & Practice $(\mathrm{P})$ & Latitude & Longitude \\
\hline Kyaesargone & GAP & $20^{\circ} 33^{\prime} 28.16 " \mathrm{~N}$ & $96^{\circ} 54^{\prime} 2.917^{\prime \prime} \mathrm{E}$ \\
& non-GAP & $20^{\circ} 33^{\prime} 54.39 " \mathrm{~N}$ & $96^{\circ} 54^{\prime} 13.02^{\prime \prime} \mathrm{E}$ \\
Kaylar & GAP & $20^{\circ} 29^{\prime} 54.39 " \mathrm{~N}$ & $96^{\circ} 54^{\prime} 13.02^{\prime \prime} \mathrm{E}$ \\
& non-GAP & $20^{\circ} 30^{\prime} 15.54 " \mathrm{~N}$ & $96^{\circ} 54^{\prime} 52.36^{\prime \prime} \mathrm{E}$ \\
Ngaphaechaung & GAP & $20^{\circ} 30^{\prime} 51.77 " \mathrm{~N}$ & $9^{\circ} 53^{\prime} 55.31^{\prime \prime} \mathrm{E}$ \\
& non-GAP & $20^{\circ} 30^{\prime} 41.43 " \mathrm{~N}$ & $96^{\circ} 53^{\prime} 55.78^{\prime \prime} \mathrm{E}$ \\
Zayatgyi & GAP & $20^{\circ} 28^{\prime} 53.49 " \mathrm{~N}$ & $96^{\circ} 54^{\prime} 26.87^{\prime \prime} \mathrm{E}$ \\
& non-GAP & $20^{\circ} 29^{\prime} 13.97 " \mathrm{~N}$ & $96^{\circ} 54^{\prime} 30.21^{\prime \prime} \mathrm{E}$ \\
\hline Central lake & & $20^{\circ} 34^{\prime} 27.15 " \mathrm{~N}$ & $96^{\circ} 55^{\prime} 3.809^{\prime \prime} \mathrm{E}$ \\
Inlet stream & & $20^{\circ} 32^{\prime} 30.62^{\prime \prime} \mathrm{N}$ & $96^{\circ} 50^{\prime} 5.832^{\prime \prime} \mathrm{E}$ \\
\hline
\end{tabular}

\section{Precipitation and temperature}

The weather conditions for the years 2019 and 2020 at Nyaung Shwe Township, Southern Shan State, Myanmar is shown in Figure 2 [15]. Precipitation started in May, 2019, while it started in April, 2020. There was a large increase in rainfall $(395 \mathrm{~mm})$ in August, 2019 . Maximum temperature $\left(38^{\circ} \mathrm{C}\right)$ was found in April for both years.

\section{Water sampling and analyses}

Surface water samples were collected from each study site with three replications on 27 July 2019 (wet season) and 25 April 2020 (dry season). Surface water was measured in situ from GAP and non-GAP sites for the parameters; temperature, $\mathrm{pH}$, electrical conductivity and dissolved oxygen (DO) using a HACH HQ40d Portable meter [16]. Water samples were collected to determine alkalinity, total hardness, biochemical oxygen demand (BOD), chemical oxygen demand (COD) and nutrient analyses. Samples were stored in a cool ice box, and transported from the field to the laboratory at constant temperatures of 4-6 ${ }^{\circ} \mathrm{C}$ until analysis. Total alkalinity was measured by titration method [17]. Total hardness was calculated by using the concentration of calcium $\left(\mathrm{Ca}^{2+}\right)$, and magnesium $\left(\mathrm{Mg}^{2+}\right)$ according to [18]. BOD and COD were measured by BOD measurement system-BD 600 and COD measurement system-MD 200 , respectively. The concentration of nitrate ion $\left(\mathrm{NO}_{3}{ }^{-}\right)$, ammonium ion $\left(\mathrm{NH}_{4}{ }^{+}\right)$were analyzed by lon Chromatography (ISO10304-1, 2009) [19] and (ISO14911, 1998) [20] respectively, total nitrogen (N) was analyzed by Kjeldahl distillation method [21], ortho-P and total phosphorus $(P)$ were analyzed by using a continuous flow analyzer [22]. The collected samples were analyzed at the laboratory of the Department of Soil and Water Science, Yezin Agricultural University, at the laboratory of Forest 
Research Institute, and the Water Utilization Section of the Department of Agricultural Research, Yezin, Myanmar.

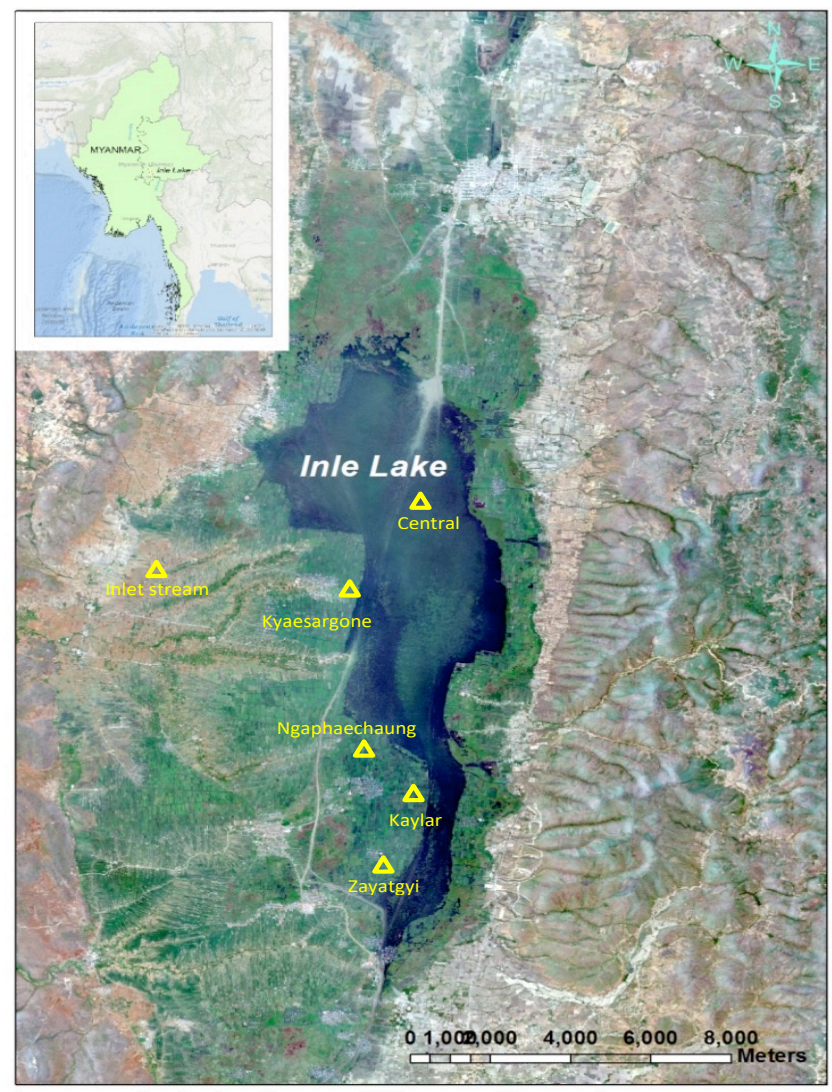

Figure 1. Study sites of floating garden in Inle Lake

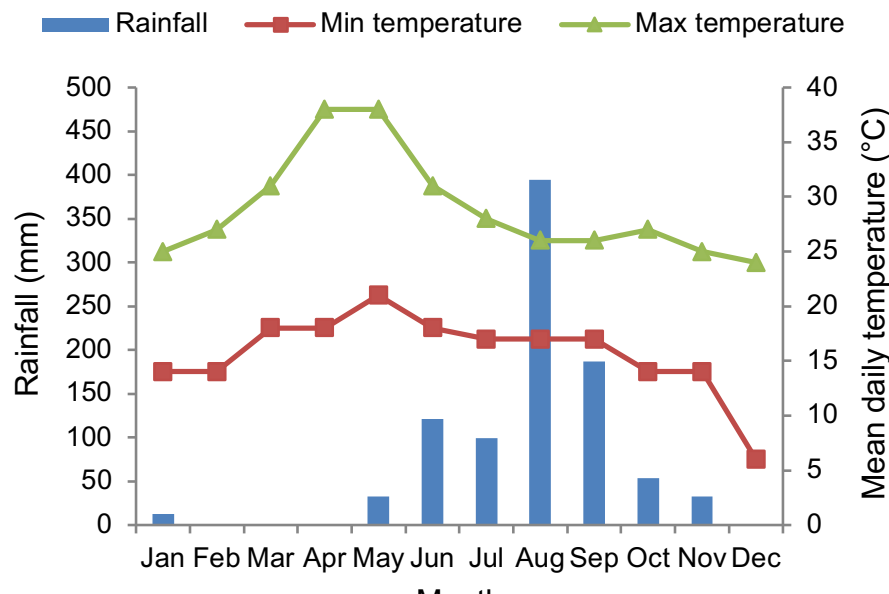

Month

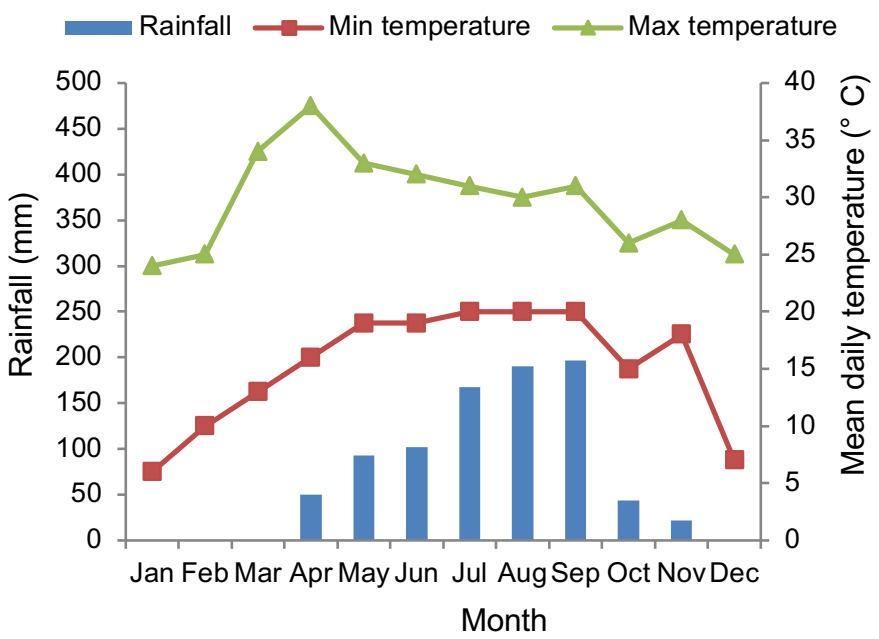

Month

Figure 2. Precipitation and temperature for the years 2019 and 2020 at Inle Lake, Myanmar [15]

\section{Water quality index calculation}

Water quality index was performed to compare water quality parameters with respective regulatory standards, which gives a single indicator to describe the overall quality of a water body [23]. WQI has been useful for assessment of water quality of a lake [24, 25]. 
In this study, nine physico-chemical parameters, i.e. $\mathrm{pH}, \mathrm{EC}, \mathrm{TDS}$, total alkalinity, total hardness, $\mathrm{Ca}^{2+}$, $\mathrm{Mg}^{2+}, \mathrm{DO}, \mathrm{BOD}$ were used to calculate WQI values by the weighted arithmetic index method according to the following Equation 1 [26].

$$
\text { Quality rating }(\mathrm{Qi})=\frac{100(\mathrm{Vn}-\mathrm{Vi})}{\mathrm{Si}-\mathrm{Vi}}
$$

where, $\mathrm{Vn}$ is the concentration of water quality parameter; $\mathrm{Vi}$ is the ideal value of $\mathrm{i}^{\text {th }}$ parameter in pure water. In most cases, Vi was 0 , and $\mathrm{pH}$, DO was 7 and 14.6, respectively; relative weight (Wi) was calculated according to the following Equation 2.

$$
\mathrm{Wi}=\frac{\mathrm{K}}{\mathrm{Si}}
$$

where, $\mathrm{K}$ is constant for proportionality; $\mathrm{Si}$ is the recommended standard value for $\mathrm{i}^{\text {th }}$ parameter [27]. The overall water quality index was mathematically expressed with the following Equation 3 [26].

$$
\mathrm{WQI}=\frac{\sum \mathrm{QiWi}}{\sum \mathrm{Wi}}
$$

Water quality was classified by the WQI ranges from 0 to 100; (1) WQI values of 0-25 is excellent water quality, (2) 25-50 is good water quality, (3) 50-75 and (4) 75-100 indicate poor and very poor water quality, respectively [26].

\section{Statistical analysis}

The data was evaluated statistically using combined analysis of variance technique, and means were compared by least significant difference (LSD) method at a 5\% confidence level. All statistical analysis was performed using Statistix 10 and Microsoft Excel 2016. In order to examine differences between two agricultural practices, a boxplot graphical method was performed for the collected water quality parameters. A boxplot presented a dataset through five statistics: extreme values (minimum and maximum values), median ( $50^{\text {th }}$ percentile), $25^{\text {th }}$ percentile, and $75^{\text {th }}$ percentile. It also showed the degree of dispersion and unusual values of the result (outliers).

\section{Results and discussion}

\section{Management practices for both GAP and non-GAP}

Farmers who practiced GAP and non-GAP from the sampling sites were questioned about their application of fertilizers and pesticides when growing tomato in their floating gardens. Management practices for both GAP and non-GAP productions are presented in Table (2). Farmers cultivated the tomato during the wet season (from May to September) and the dry season (from January to May). GAP farmers were planted tomato under GAP's protocol with applying organic, chemical and foliar fertilizers. The organic fertilizers included the dead parts of the aquatic materials, bat manure and used at transplanting time. In the sampling sites, farmers used compound fertilizers containing various ratios of nitrogen, phosphorous and potassium and foliar fertilizers. All sample farmers from GAP and non-GAP reported to have always applied organic, chemical and foliar fertilizers for their cultivation, but no one reported to have used straight fertilizers. Compound fertilizer, $15 \mathrm{~N}: 15 \mathrm{P}_{2} \mathrm{O}_{5}: 15 \mathrm{~K}_{2} \mathrm{O}$ was used in GAP and non-GAP during the vegetation (0-45 days after transplanting) and reproductive periods (46-90 days after transplanting). The fertilizers were applied with 4 times during the vegetation period and 4-6 times during the reproductive period. Farmers applied the pesticides to protect an incident of pests and diseases and the majority of insecticides used in the GAP and non-GAP were acephate, imidacloprid and abamectin. The fungicides such as mancozeb, carbendazim and cupper hydroxide were used for fungal diseases. The pesticides were sprayed with 7-10 days interval during the vegetation period and 
10 days interval during the reproductive period. The application rate and frequency for fertilizer and pesticide applications are greater in non-GAP than GAP production.

Table 2. Fertilizer and pesticide application in study villages

\begin{tabular}{|c|c|c|c|c|c|c|c|c|}
\hline \multirow{2}{*}{ Description } & \multicolumn{2}{|c|}{ Kyaesargone } & \multicolumn{2}{|c|}{ Kaylar } & \multicolumn{2}{|c|}{ Ngaphaechaung } & \multicolumn{2}{|c|}{ Zayatgyi } \\
\hline & GAP & non-GAP & GAP & non-GAP & GAP & non-GAP & GAP & non-GAP \\
\hline $\begin{array}{l}\text { Compound fertilizer } \\
\text { application (kg/ha) }\end{array}$ & 1850 & 2470 & 1850 & 2470 & 1650 & 2200 & 1850 & 2990 \\
\hline $\begin{array}{l}\text { Foliar fertilizer application } \\
\text { (kg/ha) }\end{array}$ & 2.47 & 2.47 & 2.47 & 2.47 & 1.65 & 2.47 & 2.47 & 3.74 \\
\hline Pesticide application (I/ha) & 2.20 & 3.10 & 2.40 & 3.60 & 1.35 & 2.75 & 2.45 & 3.10 \\
\hline
\end{tabular}

Table 3. Physical and chemical parameters of lake water quality as affected by different agricultural practices of tomato cultivation on the floating garden during the wet season, 2019 and dry season, 2020

\begin{tabular}{|c|c|c|c|c|c|c|c|}
\hline \multirow{2}{*}{ Site (S) } & \multirow{2}{*}{ Practice $(P)$} & \multicolumn{2}{|c|}{ Temperature $\left({ }^{\circ} \mathrm{C}\right)$} & \multicolumn{2}{|c|}{$\mathrm{pH}$} & \multicolumn{2}{|c|}{$E C\left(d_{S m}^{-1}\right)$} \\
\hline & & Wet & Dry & Wet & Dry & Wet & Dry \\
\hline \multirow[t]{2}{*}{ Kyaesargone } & GAP & 25.4 & 29.1 & $7.2^{\mathrm{c}}$ & 6.9 & $0.34^{\mathrm{e}}$ & $0.37^{e}$ \\
\hline & non-GAP & 25.2 & 30.0 & $7.1^{\mathrm{d}}$ & 7.0 & $0.45^{\mathrm{a}}$ & $0.39^{d}$ \\
\hline \multirow[t]{2}{*}{ Kaylar } & GAP & 25.0 & 28.8 & $7.3^{b}$ & 6.9 & $0.37^{\mathrm{cd}}$ & $0.48^{b}$ \\
\hline & non-GAP & 25.2 & 28.8 & $7.2^{\mathrm{c}}$ & 7.0 & $0.34^{\mathrm{e}}$ & $0.48^{b}$ \\
\hline \multirow[t]{2}{*}{ Ngaphaechaung } & GAP & 27.3 & 29.8 & $7.5^{\mathrm{a}}$ & 7.2 & $0.37^{\mathrm{cd}}$ & $0.51^{a}$ \\
\hline & non-GAP & 26.0 & 30.1 & $7.3^{\mathrm{b}}$ & 7.1 & $0.38^{\mathrm{bc}}$ & $0.52^{\mathrm{a}}$ \\
\hline \multirow[t]{2}{*}{ Zayatgyi } & GAP & 28.1 & 28.4 & $7.6^{\mathrm{a}}$ & 7.1 & $0.40^{\mathrm{b}}$ & $0.45^{c}$ \\
\hline & non-GAP & 25.8 & 28.7 & $7.5^{\mathrm{a}}$ & 7.1 & $0.35^{\text {cde }}$ & $0.53^{\mathrm{a}}$ \\
\hline \multicolumn{2}{|l|}{ Central lake } & 25.4 & 28.8 & 7.6 & 8.8 & 0.27 & 0.31 \\
\hline \multicolumn{2}{|l|}{ Inlet stream } & 21.3 & 24.6 & 7.1 & 7.2 & 0.44 & 0.59 \\
\hline \multicolumn{8}{|l|}{ F-test } \\
\hline \multicolumn{2}{|l|}{$\mathrm{S}$} & ** & ** & ** & * & * & ** \\
\hline \multicolumn{2}{|l|}{$\mathrm{P}$} & $*$ & * & $* *$ & ns & ns & $* *$ \\
\hline \multicolumn{2}{|l|}{ SxP } & ns & ns & * & ns & $* *$ & $* *$ \\
\hline \multicolumn{2}{|l|}{ CV\% } & 2.6 & 1.0 & 0.7 & 1.1 & 3.7 & 1.7 \\
\hline
\end{tabular}

Values in a same column followed by the same letter are not significantly different at the $5 \%$ level by the LSD test,

**significantly different at $\mathrm{P} \leq 0.01$, *significantly different at $\mathrm{P} \leq 0.05$, ns-not significant

\section{Physical and chemical parameters}

The physical and chemical parameters of water quality are presented in Table (3). Water temperature is one of the essential factors for aquatic life and it is necessarily carry out the biological activity, i.e. increase in the biological activity with higher temperature [28]. The results showed that there were significant differences in water temperature among the study sites and also significant differences between two agricultural practices in both season. However, there were no interactions between study sites and practices in both seasons. Water $\mathrm{pH}$ is also an essential parameter to assess water quality. In this study, there was significant difference in $\mathrm{pH}$ levels among the study sites and between two agricultural practices in wet season. In dry season, there was significant difference in $\mathrm{pH}$ levels among the study sites, but no significant between two agricultural practices. Moreover, there was interaction between study sites and practices in wet season, but not in dry season. The centre of the lake was the highest in $\mathrm{pH}(7.60)$ and (8.85) in wet and dry seasons, respectively.

Electrical conductivity $(E C)$ is a further common measurement used to evaluate water quality. In this study, there were significant differences in EC level among the study sites, but no significant between two agricultural practices in wet season. In dry season, significant differences were found in EC among the study sites and between two agricultural practices. Moreover, there were highly significant 
interactions between study sites and practices in both seasons. It was noted that both practices examined in each of the four villages showed low EC values in both seasons. This result was in accordance with the findings of Thin et al. [29], described that Inle lake waters were categorized by relatively low EC but higher in dry season.

Potassium $(\mathrm{K})$ is an essential element in both plant and human nutrition. In this study, there were significant differences in $\mathrm{K}^{+}$content among the studied villages and between the two agricultural practices in both seasons. There was no interaction between study sites and practices in wet season. In contrast, there was interaction in dry season, indicating that the effects of the different agricultural practices for this nutrient were dissimilar for the four villages. Sodium salt is one of the most abundant element on earth and highly soluble in water and found as ionic form $\left(\mathrm{Na}^{+}\right)$. In the present study, there was significant difference in $\mathrm{Na}^{+}$content among the studied villages, but not significant between the two practices in wet season. In dry season, there were significant differences in $\mathrm{Na}^{+}$content among the studied villages and between the two agricultural practices. Moreover, there were interactions between study sites and practices in both seasons, indicating that the effects of different agricultural practices for $\mathrm{Na}^{+}$content were different for all villages. Calcium is one of the main inorganic cation as $\mathrm{Ca}^{2+}$ ions (dissociation of calcium chloride or calcium sulphate) in saltwater and freshwater. This study found that calcium contents in surface water were not significant different among the studied villages or between the two practices in wet season. In dry season, there were significant differences in $\mathrm{Ca}^{2+}$ content among the studied villages and between the two agricultural practices. Moreover, there were interactions between study sites and practices in both seasons, which mean that the effects of different agricultural practices for this nutrient were dissimilar for four villages. It might be due to the discharge of $\mathrm{Ca}^{2+}$ from the inlet stream water entered to lake water. Magnesium is commonly found in natural water as $\mathrm{Mg}^{2+}$. In this study, Mg content was significant different among the studied villages, but not significant between the two practices in wet season. In dry season, there were significant differences in $\mathrm{Mg}^{2+}$ content among the studied villages and between the two agricultural practices. Moreover, interactions were observed between study sites and practices in both seasons, indicating that the effects of the different agricultural practices for this nutrient were different for the four villages.

Table 3(Cont'd). Physical and chemical parameters of lake water quality as affected by different agricultural practices of tomato cultivation on the floating garden during the wet season, 2019 and dry season, 2020

\begin{tabular}{|c|c|c|c|c|c|c|c|c|c|}
\hline \multirow{2}{*}{ Site (S) } & \multirow{2}{*}{ Practice $(P)$} & \multicolumn{2}{|c|}{$\mathrm{K}^{+}\left(\mathrm{mgl}^{-1}\right)$} & \multicolumn{2}{|c|}{$\mathrm{Na}^{+}\left(\mathrm{mgl}^{-1}\right)$} & \multicolumn{2}{|c|}{$\mathrm{Ca}^{2+}\left(\mathrm{mgl}^{-1}\right)$} & \multicolumn{2}{|c|}{$\mathrm{Mg}^{2+}\left(\mathrm{mgl}^{-1}\right)$} \\
\hline & & Wet & Dry & Wet & Dry & Wet & Dry & Wet & Dry \\
\hline \multirow[t]{2}{*}{ Kyaesargone } & GAP & 2.57 & $2.16^{c}$ & $9.23^{a b}$ & $6.99^{a}$ & $33.90^{c}$ & $36.41^{\mathrm{c}}$ & $14.40^{\mathrm{ef}}$ & $18.08^{\mathrm{e}}$ \\
\hline & non-GAP & 4.51 & $5.06^{b}$ & $6.93^{b c}$ & $6.22^{b}$ & $70.43^{a}$ & $21.23^{e}$ & $16.70^{\mathrm{a}}$ & $17.75^{\mathrm{e}}$ \\
\hline \multirow[t]{2}{*}{ Kaylar } & GAP & 1.64 & $1.79^{c}$ & $8.63^{a b}$ & $2.10^{d}$ & $40.77^{\mathrm{bc}}$ & $36.40^{c}$ & $15.03^{\mathrm{de}}$ & $20.35^{\mathrm{cd}}$ \\
\hline & non-GAP & 1.60 & $1.77^{\mathrm{c}}$ & $4.50^{\mathrm{cd}}$ & $2.25^{d}$ & $41.97^{\mathrm{bc}}$ & $40.66^{\mathrm{ab}}$ & $15.40^{\mathrm{cd}}$ & $21.35^{b}$ \\
\hline \multirow[t]{2}{*}{ Ngaphaechaung } & GAP & 0.50 & $1.17^{\text {de }}$ & $1.93^{\mathrm{e}}$ & $1.38^{\mathrm{e}}$ & $42.53^{b c}$ & $40.08^{b}$ & $16.13^{\mathrm{ab}}$ & $21.77^{b}$ \\
\hline & non-GAP & 0.88 & $1.29^{d}$ & $9.70^{\mathrm{a}}$ & $1.43^{\mathrm{e}}$ & $47.50^{\mathrm{bc}}$ & $44.00^{\mathrm{a}}$ & $16.17^{\mathrm{ab}}$ & $20.53^{c}$ \\
\hline \multirow[t]{2}{*}{ Zayatgyi } & GAP & 1.50 & $0.85^{e}$ & $3.03^{\text {de }}$ & $1.43^{e}$ & $51.33^{b}$ & $38.37^{b c}$ & $15.87^{\mathrm{bc}}$ & $20.00^{d}$ \\
\hline & non-GAP & 1.83 & $7.38^{a}$ & $2.97^{\mathrm{de}}$ & $5.10^{c}$ & $35.37^{c}$ & $32.36^{d}$ & $14.33^{f}$ & $23.32^{a}$ \\
\hline Central lake & & 1.25 & 1.41 & 17.30 & 8.55 & 15.70 & 5.23 & 15.07 & 18.36 \\
\hline Inlet stream & & 0.55 & 0.44 & 2.40 & 1.42 & 50.35 & 49.79 & 14.60 & 18.53 \\
\hline \multicolumn{10}{|l|}{ F-test } \\
\hline$S$ & & ** & ** & $* *$ & $* *$ & ns & ** & * & $* *$ \\
\hline $\mathrm{P}$ & & * & ** & ns & $* *$ & ns & ** & ns & $* *$ \\
\hline SxP & & ns & $* *$ & $* *$ & $* *$ & $* *$ & $* *$ & $* *$ & $* *$ \\
\hline CV\% & & 27.9 & 7.8 & 21.0 & 5.5 & 15.2 & 4.9 & 2.1 & 1.2 \\
\hline
\end{tabular}

Values in a same column followed by the same letter are not significantly different at the $5 \%$ level by the LSD test,

** significantly different at $\mathrm{P} \leq 0.01$, *significantly different at $\mathrm{P} \leq 0.05$, ns-not significant

Carbonate ion $\left(\mathrm{CO}_{3}^{--}\right)$content in collected surface water did not vary among the studied villages or between the two practices in both seasons. Moreover, there were no interactions between study sites 
and practices in both seasons, indicating that the effects of the different agricultural practices for carbonate ion were similar for the four villages. There were no significant differences in bicarbonate ion $\left(\mathrm{HCO}_{3}{ }^{-}\right)$content among the studied villages and between two practices in wet season. Its content in dry season was highly significant different among the studied villages, while it was not different between two agricultural practices. There was no interaction between study sites and practices in wet season while interaction was found in dry season. Chloride ion $\left(\mathrm{Cl}^{-}\right)$enters surface waters with the weathering of some sedimentary rocks (mostly rock salt deposits), from disposal of industrial and sewage effluents, from agricultural run-off [30]. In this study, $\mathrm{Cl}^{-}$in surface water did not different among the studied villages or between the two practices in wet season. However, in dry season, there were significant differences in $\mathrm{Cl}^{-}$among the studied villages and between the two agricultural practices. Moreover, there was no interaction between study sites and practices in wet season while interaction in dry season.

Table 3(Cont'd). Physical and chemical parameters of lake water quality as affected by different agricultural practices of tomato cultivation on the floating garden during the wet season, 2019 and dry season, 2020

\begin{tabular}{|c|c|c|c|c|c|c|c|}
\hline \multirow{2}{*}{ Site (S) } & \multirow{2}{*}{ Practice $(P)$} & \multicolumn{2}{|c|}{$\mathrm{CO}_{3}^{2-}\left(\mathrm{mgl}^{-1}\right)$} & \multicolumn{2}{|c|}{$\mathrm{HCO}_{3}^{-}\left(\mathrm{mgl}^{-1}\right)$} & \multicolumn{2}{|c|}{$\mathrm{Cl}^{-}\left(\mathrm{mgl}^{-1}\right)$} \\
\hline & & Wet & Dry & Wet & Dry & Wet & Dry \\
\hline \multirow[t]{2}{*}{ Kyaesargone } & GAP & 30.00 & 45.20 & 184.23 & $151.69^{b}$ & 79.53 & $18.09^{a}$ \\
\hline & non-GAP & 22.40 & 62.00 & 218.77 & $106.14^{d}$ & 86.10 & $12.07^{\mathrm{b}}$ \\
\hline \multirow[t]{2}{*}{ Kaylar } & GAP & 54.00 & 55.60 & 105.73 & $121.59^{c d}$ & 66.90 & $6.40^{c}$ \\
\hline & non-GAP & 32.00 & 51.60 & 158.60 & $120.78^{c d}$ & 72.90 & $6.15^{\mathrm{c}}$ \\
\hline \multirow[t]{2}{*}{ Ngaphaechaung } & GAP & 30.40 & 81.20 & 201.30 & $146.40^{\mathrm{bc}}$ & 63.58 & $6.16^{c}$ \\
\hline & non-GAP & 38.00 & 76.40 & 178.12 & $190.32^{a}$ & 74.03 & $6.17^{c}$ \\
\hline \multirow[t]{2}{*}{ Zayatgyi } & GAP & 47.20 & 78.40 & 185.43 & $115.90^{d}$ & 71.27 & $4.02^{d}$ \\
\hline & non-GAP & 31.20 & 54.80 & 175.63 & $150.47^{b}$ & 64.13 & $17.59^{a}$ \\
\hline Central lake & & 46.20 & 63.27 & 262.90 & 118.60 & 74.05 & 12.55 \\
\hline Inlet stream & & 30.00 & 63.73 & 212.83 & 118.37 & 69.93 & 4.37 \\
\hline \multicolumn{8}{|l|}{ F-test } \\
\hline S & & ns & ns & ns & ** & ns & ** \\
\hline $\mathrm{P}$ & & ns & ns & ns & ns & ns & ** \\
\hline SxP & & ns & ns & ns & $* *$ & ns & $* *$ \\
\hline CV\% & & 29.5 & 22.8 & 27.2 & 9.7 & 18.3 & 3.4 \\
\hline
\end{tabular}

Values in a same column followed by the same letter are not significantly different at the $5 \%$ level by the LSD test,

** significantly different at $\mathrm{P} \leq 0.01$, *significantly different at $\mathrm{P} \leq 0.05$, ns-not significant

Sodium and chloride are principal components of total dissolved solids (TDS). In this study, the results showed that significant differences were observed in TDS among the study sites and also between two agricultural practices in wet season. The data in dry season showed that there were no significant differences in TDS among the study sites and also between two agricultural practices. On the other hand, there was interaction between study sites and practices in wet season, but it was not in dry season. Total suspended solids (TSS) are sediments, organic residues, and other solid materials which are suspended in the water body. The results showed that there was no significant difference in TSS among the study sites and also no significant difference between GAP and non-GAP in wet season. In dry season showed that significant differences were found in TDS among the study sites and also between two agricultural practices. No interaction was observed between study sites and practices in the wet season, but interaction was found in dry season.

Alkalinity is an indicator of acid-neutralization capacity of natural waters. Carbonates, bicarbonates, and hydroxides are common components of alkalinity. $\mathrm{pH}$ changes in water body throughout the day due to respiration of animals and photosynthesis of plants. Alkalinity is important for aquatic system because it buffers $\mathrm{pH}$ changes. Carbonate and bicarbonate combine with some heavy metals and reduce their toxicity [31]. In this study, total alkalinity in water did not vary among the studied villages or between the two practices in wet season. In dry season, there was highly significant difference in total alkalinity among the studied villages, but not significant difference between the two practices. There was no interaction between study sites and practices in wet season, but interaction in dry season. The total alkalinity is very 
high in each of the villages in both seasons. This result might be due to the present of high content of carbonate $\left(\mathrm{CO}_{3}{ }^{2-}\right)$, bicarbonate $\left(\mathrm{HCO}_{3}{ }^{-}\right)$, phosphate $\left(\mathrm{PO}_{4}{ }^{3-}\right)$ and hydroxide $\left(\mathrm{OH}^{-}\right)$[31]. Due to high concentration of total alkalinity can affect ammonia toxicity and algal blooming, variation water quality and damage aquatic life.

There were significant differences in total hardness both for four study sites and two agricultural practices at $5 \%$ level in wet season. The results in dry season found that there were significant differences in total hardness among the studied villages, and between the two practices. Moreover, interaction was observed between study sites and practices in both seasons, indicating that the effects of different agricultural practices for this nutrient were different for four villages. Higher values of total hardness in this study may be due to natural source of limestone and transported increased flow from an inlet stream to the lake with the values (185.43 $\mathrm{mgl}^{-1}$ in wet and $201.45 \mathrm{mgl}^{-1}$ in dry). Akaishi et al. [4] found that Inle surface water contain the main cation $\mathrm{Ca}^{2+}$ and anion $\mathrm{HCO}_{3}{ }^{-}$. The sum of the concentration of alkaline earth metals cations refers to the total hardness, can divide into three categories as very hard (>300 $\mathrm{mgl}^{-}$ $\left.{ }^{1}\right)$, hard (151-300 $\left.\mathrm{mgl}^{-1}\right)$, moderately hard $\left(75-150 \mathrm{mgl}^{-1}\right)$ and soft $\left(0-75 \mathrm{mgl}^{-1}\right)$ by [32]. According to this classification, lake water falls in the category of hard in both seasons (Table 3).

Table 3(Cont'd). Physical and chemical parameters of lake water quality as affected by different agricultural practices of tomato cultivation on the floating garden during the wet season, 2019 and dry season, 2020

\begin{tabular}{|c|c|c|c|c|c|c|c|c|c|}
\hline \multirow{2}{*}{ Site (S) } & \multirow{2}{*}{ Practice $(P)$} & \multicolumn{2}{|c|}{$\begin{array}{c}\text { Total Dissolved } \\
\text { Solid }\left(\mathrm{mgl}^{-1}\right)\end{array}$} & \multicolumn{2}{|c|}{$\begin{array}{l}\text { Total Suspended } \\
\text { Solid }\left(\mathrm{mgl}^{-1}\right)\end{array}$} & \multicolumn{2}{|c|}{$\begin{array}{c}\text { Total Alkalinity } \\
\left(\mathrm{mgl}^{-1}\right)\end{array}$} & \multicolumn{2}{|c|}{$\begin{array}{c}\text { Total Hardness } \\
\left(\mathrm{mgl}^{-1}\right)\end{array}$} \\
\hline & & Wet & Dry & Wet & Dry & Wet & Dry & Wet & Dry \\
\hline \multirow[t]{2}{*}{ Kyaesargone } & GAP & $285.3^{d}$ & 279.3 & 98.5 & $15.0^{\mathrm{bc}}$ & 241.2 & $915.6^{b}$ & $143.95^{c}$ & $165.36^{c}$ \\
\hline & non-GAP & $356.3^{a}$ & 218.0 & 92.6 & $10.3^{\text {cde }}$ & 260.0 & $683.4^{c}$ & $261.16^{a}$ & $126.10^{d}$ \\
\hline \multirow[t]{2}{*}{ Kaylar } & GAP & $255.3^{e}$ & 204.3 & 91.2 & $4.6^{e f}$ & 212.0 & $906.0^{\mathrm{b}}$ & $163.74^{\mathrm{bc}}$ & $174.68^{\mathrm{bc}}$ \\
\hline & non-GAP & $262.6^{e}$ & 258.6 & 90.2 & $3.3^{f}$ & 212.0 & $924.6^{b}$ & $168.12^{\mathrm{bc}}$ & $189.44^{a}$ \\
\hline \multirow[t]{2}{*}{ Ngaphaechaung } & GAP & $261.6^{\mathrm{e}}$ & 282.6 & 84.2 & $21.6^{\mathrm{ab}}$ & 258.8 & $1018.2^{a}$ & $172.43^{b c}$ & $189.72^{a}$ \\
\hline & non-GAP & $266.3^{e}$ & 281.6 & 84.9 & $12.0^{\mathrm{cd}}$ & 251.2 & $1017.6^{a}$ & $185.13^{b}$ & $194.42^{a}$ \\
\hline \multirow[t]{2}{*}{ Zayatgyi } & GAP & $334.6^{b}$ & 233.0 & 91.5 & $22.0^{a}$ & 276.8 & $872.4^{b}$ & $193.51^{b}$ & $178.16^{b}$ \\
\hline & non-GAP & $310.6^{c}$ & 285.0 & 79.0 & $6.6^{\text {def }}$ & 235.2 & $1003.2^{a}$ & $147.19^{c}$ & $176.83^{b}$ \\
\hline Central lake & & 256.0 & 176.6 & 118.6 & 7.6 & 151.0 & 484.0 & 101.22 & 88.23 \\
\hline Inlet stream & & 373.6 & 295.0 & 84.7 & 144.0 & 291.0 & 900.4 & 185.43 & 201.45 \\
\hline \multicolumn{10}{|l|}{ F-test } \\
\hline S & & ** & ns & ns & $* *$ & ns & ** & * & ** \\
\hline$P$ & & ** & ns & ns & $* *$ & ns & ns & * & $*$ \\
\hline SxP & & $* *$ & ns & ns & * & ns & $* *$ & $* *$ & ** \\
\hline CV\% & & 3.2 & 14.3 & 20.2 & 28.2 & 19.8 & 3.4 & 10.0 & 2.8 \\
\hline
\end{tabular}

Values in a same column followed by the same letter are not significantly different at the $5 \%$ level by the LSD test,

** significantly different at $\mathrm{P} \leq 0.01$, *significantly different at $\mathrm{P} \leq 0.05$, ns-not significant

Table 4 shows nutrients content in the Inle Lake water during wet season, 2019 and dry season, 2020. The results showed that total $\mathrm{N}$ content in surface water did not vary among the studied villages or between the two practices in wet season. Significant differences were observed in total $\mathrm{N}$ content among the studied villages, but it was not different between two agricultural practices in dry season. There were no interactions between study sites and practices in both seasons. Total $\mathrm{N}$ from the studied villages was higher compared with a central lake in wet $\left(0.17 \mathrm{mgl}^{-1}\right)$ and dry season $\left(0.12 \mathrm{mgl}^{-1}\right)$. It was noted that the surface water from most of the studied villages can be classified as eutrophic on the basis of the high nitrogen concentrations in the lake water due to over use of fertilizers by farmers. There were significant differences in nitrate $\left(\mathrm{NO}_{3}{ }^{-}\right)$content among the studied villages and between the two agricultural practices in wet season. Highly significant differences were observed in $\mathrm{NO}_{3}{ }^{-}$content among the studied villages and between the two agricultural practices in dry season. Interactions were observed in both seasons, indicating that the effects of the different agricultural practices for this nutrient were not the same for the four villages. $\mathrm{NO}_{3}$ - content was high in floating area when compared to inlet stream in both seasons. It might be indicated that low amount of nutrients are discharging from the watershed areas 
but it comes from tomato production. $\mathrm{NO}_{3}{ }^{-}$is low toxic but it might endogenously convert to nitrite $\left(\mathrm{NO}_{2}{ }^{-}\right.$ ), which becomes toxic to human health and aquatic organisms [33, 34, and 35]. Nitrogenous fertilizers from non-point source pollution is critical in ecosystem [36] and in agro-ecosystems, surface water pollution was strictly related to agricultural action.

Table 4. Nutrients content in Inle Lake water as affected by different agricultural practices of tomato cultivation on the floating garden during the wet season, 2019 and dry season, 2020

\begin{tabular}{|c|c|c|c|c|c|c|c|c|c|}
\hline \multirow{2}{*}{ Site (S) } & \multirow{2}{*}{ Practice $(P)$} & \multicolumn{2}{|c|}{ Total N $\left(\mathrm{mgl}^{-1}\right)$} & \multicolumn{2}{|c|}{$\mathrm{NO}_{3}^{-}\left(\mathrm{mgl}^{-1}\right)$} & \multicolumn{2}{|c|}{ Total P $\left(\mathrm{mgl}^{-1}\right)$} & \multicolumn{2}{|c|}{ Ortho-P $\left(\mathrm{mgl}^{-1}\right)$} \\
\hline & & Wet & Dry & Wet & Dry & Wet & Dry & Wet & Dry \\
\hline \multirow[t]{2}{*}{ Kyaesargone } & GAP & 1.93 & 1.82 & $0.022^{\mathrm{c}}$ & $0.16^{a b}$ & 0.26 & $0.26^{\mathrm{bc}}$ & 0.26 & 0.23 \\
\hline & non-GAP & 2.24 & 2.18 & $0.019^{c}$ & $0.17^{\mathrm{a}}$ & 0.29 & $0.35^{\mathrm{ab}}$ & 0.29 & 0.18 \\
\hline \multirow[t]{2}{*}{ Kaylar } & GAP & 1.67 & 0.95 & $0.024^{c}$ & $0.13^{\mathrm{cd}}$ & 0.09 & $0.10^{\mathrm{d}}$ & 0.08 & 0.09 \\
\hline & non-GAP & 1.65 & 1.21 & $0.021^{\mathrm{c}}$ & $0.05^{\mathrm{e}}$ & 0.23 & $0.12^{d}$ & 0.21 & 0.11 \\
\hline \multirow[t]{2}{*}{ Ngaphaechaung } & GAP & 1.75 & 0.86 & $0.022^{c}$ & $0.16^{a b}$ & 0.04 & $0.07^{d}$ & 0.03 & 0.04 \\
\hline & non-GAP & 1.88 & 1.24 & $0.022^{c}$ & $0.14^{\mathrm{bc}}$ & 0.08 & $0.10^{d}$ & 0.06 & 0.07 \\
\hline \multirow[t]{2}{*}{ Zayatgyi } & GAP & 1.60 & 1.76 & $0.172^{b}$ & $0.04^{e}$ & 0.06 & $0.15^{\mathrm{cd}}$ & 0.05 & 0.23 \\
\hline & non-GAP & 2.15 & 2.33 & $0.286^{a}$ & $0.10^{d}$ & 0.14 & $0.46^{a}$ & 0.13 & 0.38 \\
\hline Central lake & & 0.17 & 0.12 & 0.022 & 0.07 & 0.02 & 0.01 & 0.02 & 0.01 \\
\hline Inlet stream & & 0.38 & 0.14 & 0.020 & 0.07 & 0.01 & 0.05 & 0.01 & 0.04 \\
\hline \multicolumn{10}{|l|}{ F-test } \\
\hline S & & ns & * & ** & $* *$ & ** & ** & ** & ** \\
\hline $\mathrm{P}$ & & ns & ns & * & $* *$ & * & ** & * & ns \\
\hline SxP & & ns & ns & $*$ & $* *$ & ns & * & ns & ns \\
\hline CV\% & & 20.6 & 34.4 & 29.8 & 11.4 & 34.7 & 32.1 & 33.9 & 37.5 \\
\hline
\end{tabular}

Values in a same column followed by the same letter are not significantly different at the $5 \%$ level by the LSD test,

**significantly different at $\mathrm{P} \leq 0.01$, *significantly different at $\mathrm{P} \leq 0.05$, ns-not significant

Table 5. BOD, COD and DO in the Inle Lake water as affected by different agricultural practices of tomato cultivation on the floating garden during the wet season, 2019 and dry season, 2020

\begin{tabular}{|c|c|c|c|c|c|c|c|}
\hline \multirow{2}{*}{ Site $(S)$} & \multirow{2}{*}{ Practice $(P)$} & \multicolumn{2}{|c|}{$\mathrm{BOD}\left(\mathrm{mgl}^{-1}\right)$} & \multicolumn{2}{|c|}{ COD $\left(\mathrm{mgl}^{-1}\right)$} & \multicolumn{2}{|c|}{$\mathrm{DO}\left(\mathrm{mgl}^{-1}\right)$} \\
\hline & & Wet & Dry & Wet & Dry & Wet & Dry \\
\hline Kyaesargone & GAP & $2.00^{d}$ & 4.33 & $6.00^{\mathrm{bc}}$ & 5.00 & 7.57 & 4.65 \\
\hline Kaylar & $\begin{array}{l}\text { non-GAP } \\
\text { GAP } \\
\text { non-GAP }\end{array}$ & $\begin{array}{l}9.67^{a} \\
2.33^{d} \\
8.00^{a b}\end{array}$ & $\begin{array}{l}5.96 \\
3.68 \\
5.43\end{array}$ & $\begin{array}{c}14.33^{\mathrm{a}} \\
5.00^{\mathrm{bc}} \\
14.33^{\mathrm{a}}\end{array}$ & $\begin{array}{l}6.40 \\
5.40 \\
6.00\end{array}$ & $\begin{array}{l}7.26 \\
7.64 \\
6.75\end{array}$ & $\begin{array}{l}4.59 \\
4.73 \\
4.03\end{array}$ \\
\hline Ngaphaechaung & GAP & $1.00^{\mathrm{d}}$ & 3.05 & $4.00^{\mathrm{bc}}$ & 5.40 & 7.60 & 7.28 \\
\hline & non-GAP & $1.00^{d}$ & 5.15 & $3.00^{c}$ & 6.87 & 7.34 & 7.20 \\
\hline Zayatgyi & GAP & $5.00^{c}$ & 3.94 & $7.33^{b}$ & 6.20 & 7.50 & 4.80 \\
\hline & non-GAP & $6.33^{b c}$ & 5.90 & $5.00^{\mathrm{bc}}$ & 9.60 & 6.90 & 4.29 \\
\hline Central lake & & 3.00 & 1.60 & 6.50 & 3.70 & 8.26 & 9.11 \\
\hline Inlet stream & & 2.00 & 5.10 & 7.50 & 3.30 & 7.53 & 8.89 \\
\hline F-test & & & & & & & \\
\hline S & & ** & ns & ** & * & ns & ** \\
\hline$P$ & & ** & ** & ns & * & ns & ns \\
\hline SxP & & ** & ns & ** & ns & ns & ns \\
\hline CV \% & & 22.0 & 18.6 & 25.2 & 17.9 & 6.4 & 5.9 \\
\hline
\end{tabular}

Values in a same column followed by the same letter are not significantly different at the $5 \%$ level by the LSD test, ** ${ }^{*}$ ignificantly different at $P \leq 0.01$, *significantly different at $P \leq 0.05$, ns-not significant

$\mathrm{BOD}=$ biochemical oxygen demand; $\mathrm{COD}=$ chemical oxygen demand; $\mathrm{DO}=$ dissolved oxygen

The result indicated that there were significant differences in total phosphorus and ortho-P content among the studied villages and between two agricultural practices in wet season. Total phosphorus $\left(0.29 \mathrm{mgl}^{-1}\right)$ and ortho-P $\left(0.29 \mathrm{mgl}^{-1}\right)$ were the highest values in the non-GAP area of Kyaesargone village, 
while their contents $\left(0.04\right.$ and $\left.0.03 \mathrm{mgl}^{-1}\right)$ were the lowest values in the GAP area of Ngaphaechaung. In dry season, there were significant differences in total phosphorus and ortho-P content in surface water among the studied villages. Phosphorus content from the centre of the lake and inlet stream was the lowest when compared to the four villages. However, in both seasons found that there are no interactions for total $\mathrm{P}$ and ortho- $\mathrm{P}$, indicating that the effects of the different agricultural practices for these nutrients were similar for four villages. Increased phosphorus concentrations in study areas are probably due to the higher application fertilizers for tomato production. Phosphorus levels at all agricultural practices for four villages showed an increase in concentrations greater than $0.03 \mathrm{mgl}^{-1}$, which results in the possibility of an enhanced eutrophic status [37]. They reported that Oligotrophic lakes have phosphorus concentration below $0.0101 \mathrm{mgl}^{-1}$, Mesotropic lakes contains between 0.010 and $0.020 \mathrm{mgl}^{-1}$ and phosphorus level greater than $0.020 \mathrm{mgl}^{-1}$ is an indication of Eutrophic lakes. This finding was similar with the results of Akaishi et al. [6]. Authors mentioned that the water runoff from domestic and agricultural uses could have relatively high concentrations of phosphorus, nitrite, and nitrate. Ansari et al. [38] observed that the significant amount of phosphate in surface water may result from excess phosphate that cannot take up by plants. It was noted that the high nitrogen and phosphorus concentrations in tomato floating gardens could be caused by excessive application of fertilizers. The lake was affected by high nutrient concentrations, which results in high productivity and oxygen deficiency [37]. It was suggested that agriculture fields are probably the main source for nitrogen and phosphate.

Table 5 presents BOD, COD and DO in lake water during the wet season, 2019 and dry season 2020. The biochemical oxygen demand (BOD) is one of an indicator of water quality measured the amount of biodegradable organic matter present in water sample by aerobic biological organisms. In the present study, there were significant differences in BOD in surface water among the studied villages and between the two practices in wet season. Furthermore, there was interaction between study sites and practices. In dry season, there were no significant differences in BOD among the studied villages, but significant differences for the two practices. However, there was no interaction between study sites and practices. The greater the BOD value might be suggested that some study villages used more chemical fertilizers. Increase in BOD indicates the greater amount of organic matters available for oxygen consuming bacteria and resulted in oxygen depletion and lowering dissolved oxygen (DO), this reflects aquatic organisms lead to stress, suffocate and die [39].

Chemical oxygen demand (COD) measures the amount of oxygen needed to chemically oxidize all organic and inorganic compounds in the water [40]. The result found that there was a highly significant difference in COD among the studied villages, but no difference was measured between the two practices in wet season. The result in the dry season showed that there were significant differences in COD among the studied villages and between the two practices. A highly interaction was observed between study sites and practices in wet season, but it was not in dry season. COD concentration may be controlled by a primary production of plant matter and decomposition rates [41]. The amount of oxygen dissolved in water body is called dissolved oxygen (DO), expressed in $\mathrm{mgl}^{-1} \mathrm{O}_{2}$. DO enter from the atmosphere and photosynthesis of aquatic plants, important for aquatic life, the degree of pollution, lake's health [42]. In this study, there was no significant difference in DO among the studied villages or for the two practices surveyed in wet season but a highly significant difference in DO among the studied villages, but not different between the two practices in dry season. Moreover, there were no interactions between study sites and practices in both seasons, indicating that the effects of the different agricultural practices for DO were dissimilar for four villages. The low DO conditions might have been caused by agricultural runoff containing higher organic load.

Comparison of nutrient concentrations between GAP and non-GAP Figure 3(a) shows that mean values of total nitrogen concentration in surface water revealed the same trend in both seasons. Comparing the two agricultural practices, it was significantly lower in surface water sampled from GAP than non-GAP $(P=0.025)$. Figure 3(b) shows that mean values of $\mathrm{NO}_{3}{ }^{-}$concentration was recorded the same trend in both seasons, but it was higher in GAP practice than non-GAP $(P=0.170)$. Figure $3(\mathrm{c})$ shows that $\mathrm{NH}_{4}{ }^{+}$concentration was recorded a significantly lower in GAP than non-GAP $(P=0.037)$. This low $\mathrm{NH}_{4}{ }^{+}$concentration in GAP may be due to the low amount of fertilizer 
application by farmers. Bhateria and Jain [43] reported that $\mathrm{NH}_{4}{ }^{+}$concentrations are usually low in oxygenated waters of lakes because it change to $\mathrm{N}$ oxidized forms by nitrification. The result of total $\mathrm{P}$ between GAP and non-GAP was significantly differ for both seasons, but the mean concentrations of these nutrients in GAP were less than in non-GAP (Figure 3(d) and (e)). Figure 3(f) shows that the $\mathrm{K}$ concentration was higher in lake water from GAP practice than non-GAP practice $(P=0.067)$. According to these results, Inle Lake water was affected by high nutrient concentrations due to non-GAP tomato production.

(a)

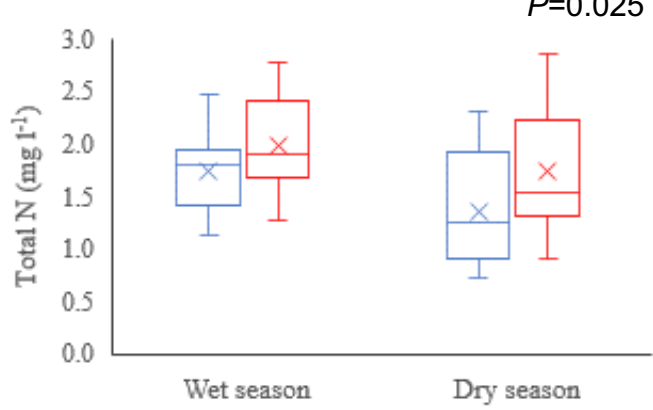

(c)
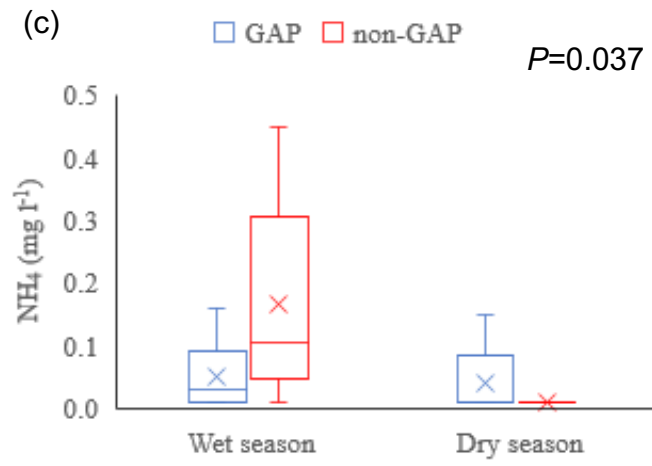

(e) $\quad \square$ GAP $\square$ non-GAP

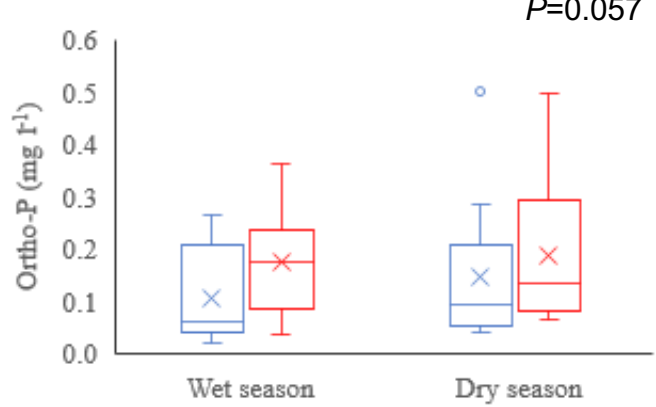

(b)
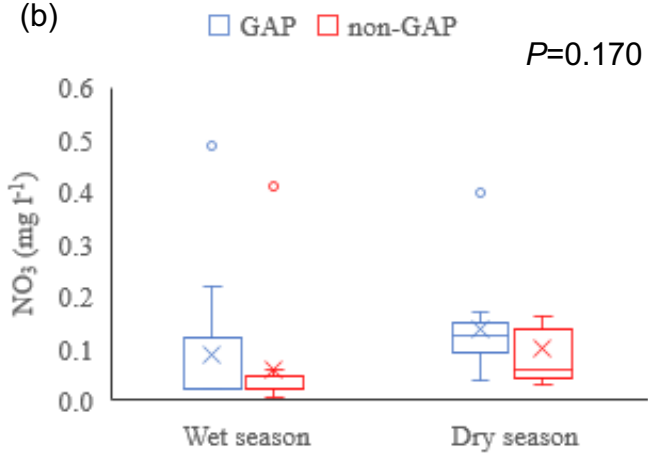

(d)

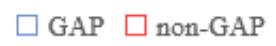

$P=0.005$

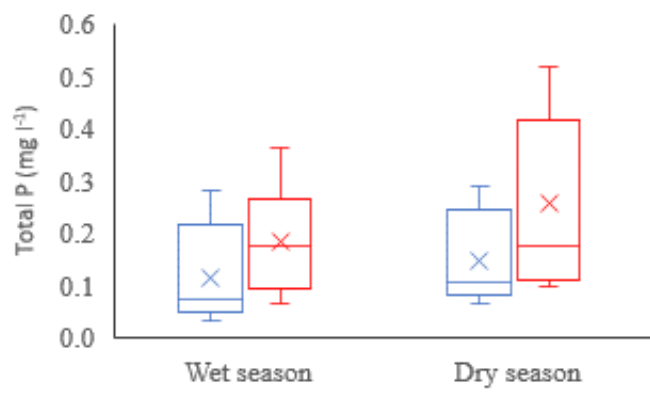

(f)

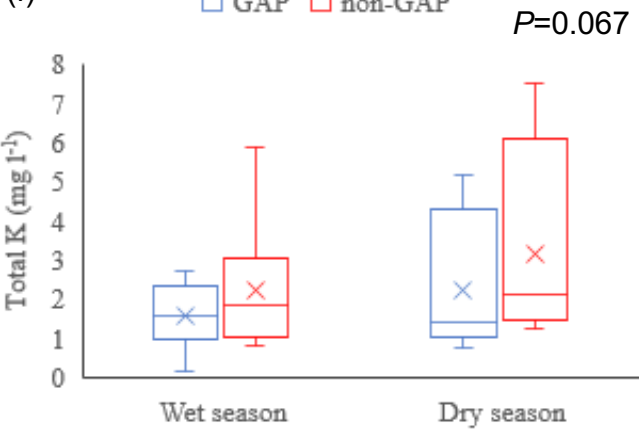

Figure 3. Comparison analysis of nutrient concentrations between agricultural practices by seasons. B ox plots represent median concentration (solid line in box), mean (x), Points on extreme top and botto $\mathrm{m}$ represent high and low outliers (samples; $n=12$ ).

Comparison of BOD, COD and DO concentrations between GAP and non-GAP

The results of $B O D$ and $C O D$ concentrations differed appreciably in both seasons (Figure 4(a) and (b)). The mean value of BOD and COD in GAP was significantly lower than that non-GAP, $(P=0.000$ for BOD 
and $P=0.003$ for $C O D)$. Increase in $B O D$ concentration results from a consequence of causing oxygen depletion and lowering dissolved oxygen. High concentration of BOD and COD in the non-GAP might be due to high amount of nutrients discharged from the floating garden and consequently the amount of oxygen needed to chemically oxidize all organic and inorganic compounds in the water body [40].

Figure 4(c) shows that DO was not significant $(P=0.172)$ between two practices, but it was lower in GAP than non-GAP in the dry season. This might be affected by warmer temperature in dry season, which can cause limiting for aquatic life. Higher concentrations of DO occurred for both practices during the wet season because it might be the increasing solubility of oxygen with low temperature, high water level and cloudy weather. Nevertheless, the DO values in the lake were very low by non-GAP and this might negatively impact the physiology and/or behavior of organisms through the effect of hypoxia [44]. DO in surface water is influenced by temperature; cold water can hold more DO than warm water. The high temperatures can have an increase in microbial activity that consumes oxygen due to decomposition of organic matter $[28,45]$.
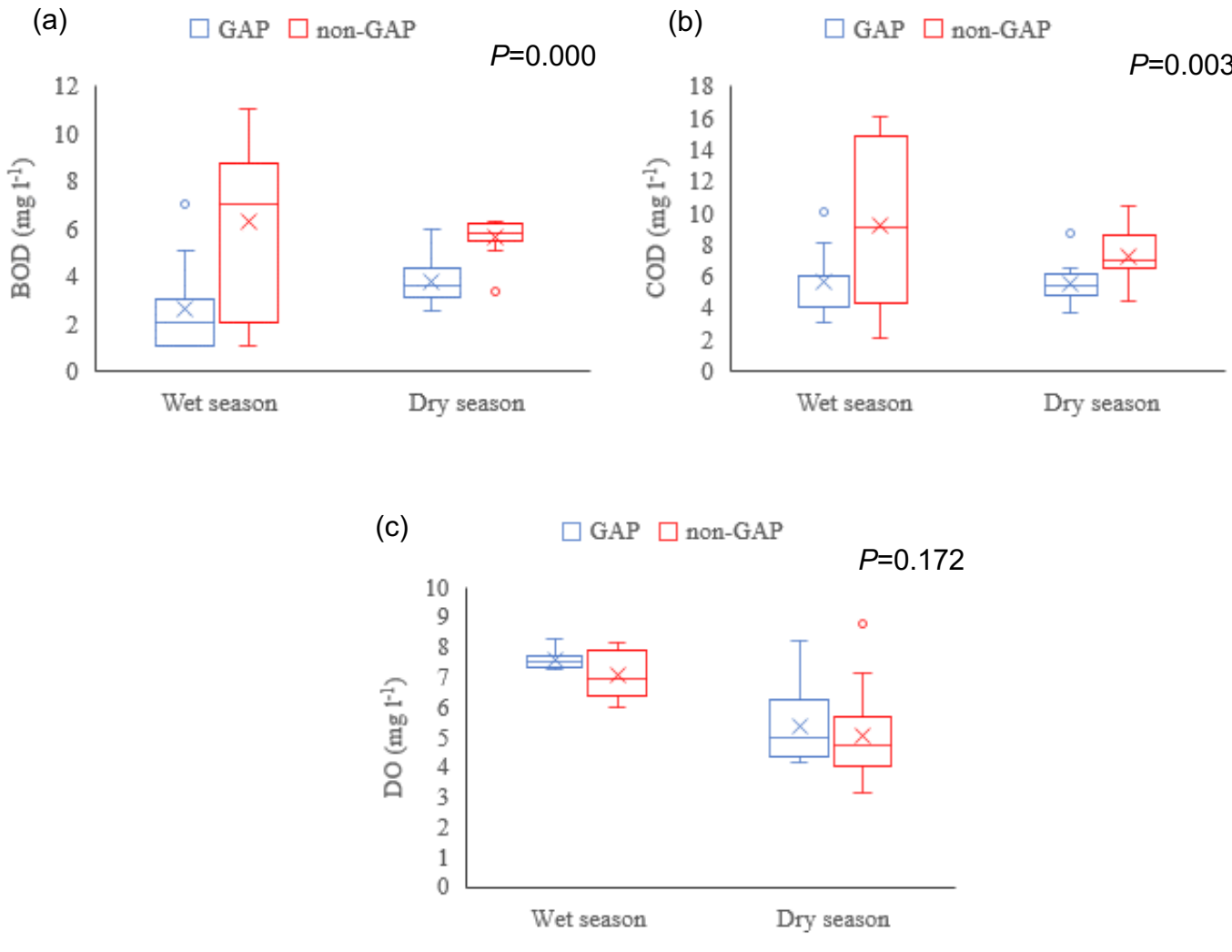

Figure 4. Comparison analysis of BOD, COD and DO concentrations between GAP and non-GAP by seasons. Box plots represent median concentration (solid line in box), mean (x), Points on extreme top and bottom represent high and low outliers (samples; $n=12$ ).

\section{Assessment of water quality}

The WQI value of GAP and non-GAP for the study sites in Inle Lake during wet season of 2019 and dry season of 2020 is presented in Table (6). In wet season, the values in GAP showed that the highest WQI were found in the tomato production of Zayatgyi village (66.54), which was followed by Kalar (51.56) and Kyaesargone (47.88). In contrast, the lowest WQI with the value of 46.63 was observed in Ngaphaechaung village among the four villages, indicating that this might be low organic pollution by agriculture production. According to the classification of water quality [25], the results indicated that GAP provided a good water quality, except Zayatgyi village. The values from non-GAP revealed that the highest WQI were found in the tomato production of Kyaesargone village (87.59), which was followed by Kalar (85.77) and Zayatgyi (85.36) and Ngaphaechaung (78.70). The water quality as affected by non- 
GAP practice in these villages classified as a very poor condition, probably due to the high organic pollutant from agrochemicals. The values from GAP in dry season showed that the highest WQI were found in the tomato production of Kyaesargone village (75.62), which was followed by Zayatgyi (75.19) village and Kalar (71.43) village while it was the lowest in the Ngaphaechaung village (61.97). In nonGAP, the highest WQI were found in the tomato production of Zayatgyi village (90.72), which was followed by Kalar village (87.48) and Kyaesargone (85.46) village. In contrast, it was the lowest in the Ngaphaechaung village (75.45). According to the classification of water quality [25], the water quality analyzed in these villages in dry season classified as a very bad condition in the non-GAP practice, probably due to the high organic pollutant of nutrients release from floating gardens. In comparison between two agricultural practices, the GAP system gave the lower WQI value than the non-GAP. This might probably be due to the higher tomato production with the excessive usage of fertilizers in the nonGAP system than in the GAP. The WQI indicated that the water quality was almost threatened in the floating garden areas. However, the surface water quality of central lake was not affected by pollution in both seasons.

Table 6. Water Quality Index of the GAP and non-GAP in Inle Lake during the wet season, 2019 and dry season, 2020

\begin{tabular}{|c|c|c|c|c|}
\hline \multirow{3}{*}{ Sites } & \multicolumn{4}{|c|}{ Water Quality Index } \\
\hline & \multicolumn{2}{|c|}{ Wet season, 2019} & \multicolumn{2}{|c|}{ Dry season, 2020} \\
\hline & GAP & non-GAP & GAP & non-GAP \\
\hline Kyaesargone & 47.88 & 87.59 & 75.62 & 85.46 \\
\hline Kaylar & 51.56 & 85.77 & 71.43 & 87.48 \\
\hline Ngaphaechaung & 46.63 & 78.70 & 61.97 & 75.45 \\
\hline Zayatgyi & 66.54 & 85.36 & 75.19 & 90.72 \\
\hline Central lake & \multicolumn{2}{|c|}{49.35} & \multicolumn{2}{|c|}{40.03} \\
\hline Inlet stream & \multicolumn{2}{|c|}{48.99} & \multicolumn{2}{|c|}{54.83} \\
\hline
\end{tabular}

\section{Conclusions}

This study attempted to investigate the water quality of Inle Lake and how it has been affected by the different agricultural practices used in tomato cultivation on floating garden beds, by measuring pollution levels. The surface water analysis results indicated that the order of cations concentration was $\mathrm{Ca}^{2+}>\mathrm{Mg}^{2+}>\mathrm{Na}^{+}>\mathrm{K}^{+}$ions and the anions was $\mathrm{HCO}_{3}{ }^{-}>\mathrm{CO}_{3}{ }^{--}>\mathrm{Cl}^{-}$. Therefore, it can be suggested that Inle lake surface water was dominated by $\mathrm{Ca}^{2+}, \mathrm{Mg}^{2+}$ and $\mathrm{HCO}_{3}{ }^{-}$and so called as $\mathrm{Ca}-\mathrm{Mg}-\mathrm{HCO}_{3}$ type, generally. The results of high nitrogen and phosphorus concentrations in both seasons were caused an increasing contamination to lake water quality. In comparison between two agricultural practices, the GAP production gave the lower WQI value than non-GAP production. It could be concluded that the extensive use of chemical fertilizers to increase agricultural production in non-GAP could be a significant source of pollution in the lake. Therefore, there would need to manage pollution sources in order to protect ecology of Inle Lake by doing management of soil, water and food safety needs attention to achieve high food production targets. GAP farming systems involves agricultural techniques which are environmentally sensitive, aim to protect natural resources, and ensure traceability and food safety, mitigates the source and transport of nutrients to environment, reduces the utilization of agrochemicals, and protect the hazards to farm labors during the crop production, harvesting and postharvest handling. This study reveal that GAP production gives an idea on the positive effects in order to reduce the impacts of floating gardens on the sustainability of lake environment and to improve the livelihoods of the peoples. There should be needed to do intensive research, education and extension activities related to GAP continue widely in the country. In this study, tomato production under GAP and non-GAP practices revealed that GAP production was more positive impact on environments than non-GAP and regarding sustainable agricultural practices with improves farmers' livelihoods and it is a better understanding of the features of farmers' awareness for good agriculture practices in this region and the whole country. 


\section{Acknowledgments}

The authors would like to thank the Integrated Land and Water Resource Management Research and Development Center in Northeast Thailand, Khon Kaen University, Thailand for Research Funding.

\section{References}

[1] N. Bassi, M.D. Kumar, A. Sharma, and P. Pardha-Saradhi, "Status of wetlands in India: A review of extent, ecosystem benefits, threats and management strategies," Journal of Hydrology: Regional. Studies, vol. 2, pp. 1-19, 2014.

[2] M.M. Thin, M. Setti, E. Sacchi, V. Re, M. P. Riccardi, and E. Allais, "Mineralogical and geochemical characterisation of alkaline lake sediments to trace origin, depositional processes, and anthropogenic impacts: Inle Lake (Southern Shan State, Myanmar)," Environmental Earth Science, vol. 79, pp. 1-18, 2020.

[3] Z. Lwin, and M. P. Sharma, "Environmental Management of the Inle Lake in Myanmar," Hydro Nepal, pp. 5760, 2012.

[4] F. Akaishi, M. Satake, M. Otaki and N. Tominaga, "Surface water quality and information about the environment surrounding Inle Lake in Myanmar," Limnology, vol. 7, pp. 57-62, 2006.

[5] K. Khurtsia, "Inle Lake conservation and rehabilitation stories from Myanmar," United Nations Development Programme (UNDP), pp. 1-71, 2015.

[6] L. E. D. Smith, and G. Siciliano, "A comprehensive review of constraints to improved management of fertilizers in China and mitigation of diffuse water pollution from agriculture." Agriculture, Ecosystems and Environment, vol. 209, pp. 15-25, 2015.

[7] J. Sierra, F. Causeret, J. L. Diman, et al., "Observed and predicted changes in soil carbon stocks under export and diversified agriculture in the Caribbean. The case study of Guadeloupe." Agriculture, Ecosystems and Environment, vol.213, pp. 252-264, 2015.

[8] M. M. Than, "Community activities contribution to water environment conservation of Inle Lake." $2^{\text {nd }}$ Int. WEPA Forum Water Environ. Gov. Asia 3-4. 2007.

[9] M. Su, and A. D. Jassby, "Inle: a large Myanmar lake in transition." Lakes and Reservoirs: Research and Management, vol.5, no.1, pp. 49-54, 2000.

[10] N. Pradhan, H. Habib, M. Venkatappa, T. Ebbers, R. Duboz, and O. Shipin, "Framework tool for a rapid cumulative effects assessment: case of a prominent wetland in Myanmar." Environmental Monitoring and Assessment, vol. 187, no. 341, 2015.

[11] DoA. "Annual Report to Ministry of Agriculture, Livestock and Irrigation, Myanmar Agriculture Service. Southern Shan State: Nyaung Shwe Township," 2018.

[12] S. Srisopaporn, D. Jourdain, S.R. Perret, and G. Shivakoti, "Adoption and continued participation in a public Good Agricultural Practices program: The case of rice farmers in the Central Plains of Thailand." Technological Forecasting and Social Change, vol.96, pp. 242-253, 2015.

[13] DoP. "The 2014 Myanmar Population and Housing Census: Shan State, Taunggyi District Nyaungshwe Township Report, Department of Population," 2017.

[14] M. Michalon, Y. Gunnell, J. Lejot, F. Mialhe, and T. Aung, "Accelerated degradation of Lake Inle (Myanmar): A baseline study for environmentalists and developers." Land Degradation and Development, vol. 30, pp. 928941, 2019.

[15] DoA. "Annual Report to Ministry of Agriculture, Livestock and Irrigation, Myanmar Agriculture Service. Southern Shan State: Nyaung Shwe Township," 2021.

[16] HACH, HQ40d Portable pH, Conductivity, Dissolved Oxygen. User Manual. HACH COMPANY, Loveland, U.S.A, 2017

[17] Hydrology Project - Technical Assistance, Standard Analytical Procedures for Water Analysis. Gov. India Gov. Netherlands, 1999

[18] L.S. Clesceri, A.E. Greenberg, and A.D. Eaton, "Standard Methods for the Examination of Water and Wastewater, 20th ed. ed. American Public Health Association, Washington, D.C," 1998.

[19] ISO 10304-1, Water quality - Determination of dissolved anions by liquid chromatography of ions. Determination of bromide, chloride, fluoride, nitrate, nitrite, phosphate and sulfate. International Organization for Standardization, 2009

[20] ISO 14911, Water quality - Determination of dissolved $\mathrm{Li}^{+}, \mathrm{Na}^{+} \mathrm{NH}_{4}{ }^{+}, \mathrm{K}^{+}, \mathrm{Mn}^{2+}, \mathrm{Ca}^{2+}, \mathrm{Mg}^{2+}, \mathrm{Sr}^{2+}$ and $\mathrm{Ba}^{2+}$ using ion chromatography - Method for water and waste water. International Organization for Standardization, 1998

[21] G. Estefan, R. Sommer, and J. Ryan, "Methods of Soil, Plant, and Water Analysis : A manual for the West Asia and North Methods of Soil, Plant, and Water Analysis: A manual for the West Asia and North Africa region." ICARDA (International Cent. Agric. Res. Dry Areas) Box 114/5055, Beirut, Lebanon 143, 2013.

[22] Skalar Analytical, B.V., Skalar Automated N \&P analyzer. Headquarters Skalar Analytical B.V., P.O.Box 3237, 
4800, DeBREDA, The Netherlands, 1993.

[23] H. Boyacioglu, "Utilization of the water quality index method as a classification tool." Environmental Monitoring and Assessment, vol. 167, pp. 115-124, 2010.

[24] K. H. Low, I. B. Koki, H. Juahir, S. Behkami, R. Ikram, H. A. Mohammed, S. M. Zain, Evaluation of water qua lity variation in lakes, rivers, and ex-mining ponds in Malaysia (review). Desalin. Water Treat., vol. 57, 58, pp 28215- 28239, 2016.

[25] I. B. Koki, S. M. Zain, K. H. Low, A. Azid, H. Juahir, M. A. Zali, "Development of water quality index of ex-min ing ponds in Malaysia." Malaysian Journal of Fundamental and Applied Sciences Vol. 15, No.1, pp. 54-60, 2 019.

[26] S. Tyagi, B. Sharma, P. Singh, and R. Dobhal, "Water Quality Assessment in Terms of Water Quality Index." American Journal of Water Resources, vol. 1, pp. 34-38, 2013.

[27] WHO, "WHO Guidelines for Drinking-Water Quality. $3^{\text {rd }}$ Edition." World Health Organization Geneva, 2008.

[28] H. A. Swenson, and H. L. Baldwin, "A primer on water quality." U.S. Dept. of the Interior, Geological Survey, pp. 1-27, 1965.

[29] M. M. Thin, E. Sacchi, and M. Setti, "Hydrological processes at Inle Lake (Southern Shan State, Myanmar) inferred from hydrochemical, mineralogical and isotopic data." Isotopes in Environmental and Health Studies, vol. 52, pp. 455-467, 2016.

[30] D. Chapman, "Water Quality Assessments - A Guide to Use of Biota, Sediments and Water in Environmental Monitoring - 2nd Edition," 1996.

[31] USEPA, "Quality Criteria for Water." United States Environmental Protection Agency (USEPA), 1986.

[32] C. Sawyer, and P. McCarthy, "Chemical and sanitary engineering, $2^{\text {nd }}$ edition." McGraw-Hill, New York, 1967.

[33] A. M. Fan, "Nitrate and Nitrite in Drinking Water: A Toxicological Review." In: Encyclopedia of Environmental Health, pp. 137-145, 2011

[34] F. Serio, P. P. Miglietta, L., Lamastra, "Groundwater nitrate contamination and agricultural land use: A grey water footprint perspective in Southern Apulia Region (Italy)." Science of the Total Environment, vol. 645, pp. 1425-1431, 2018.

[35] WHO, "Nitrate and nitrite in drinking water: background document for development of WHO guidelines for drinking water quality." Geneva World Heal. Organ, vol. 31, 2016.

[36] J. Yang, J. Liang, G. Yang, "Characteristics of non-point source pollution under different land use types." Sustainability, vol.12, 2020.

[37] D. K. Mueller, and D. R. Helsel, "Nutrients in the Nation's Waters-Too much of a good thing?" U.S. Geological Survey Circular 1136, 1996.

[38] A. A. Ansari, S. S. Gill, G. R. Lanza, and W. Rast, "Eutrophication: Causes, Consequence and control." Springer Dordrecht Heidelberg London, 2011.

[39] C. Almeida, S. Quintar, P. González, and M. Mallea, "Assessment of irrigation water quality. A proposal of a quality profile." Environmental Monitoring and Assessment, vol. 142, pp. 149-152, 2008.

[40] TCEQ, (Texas Commission on Environmental Quality), "Surface Water Quality Monitoring Procedures Manual, Volume 1: Physical and Chemical Monitoring Methods." RG-415. Austin, Texas, 2014.

[41] Mostofa, K. M. G., Liu, C. qiang, Mottaleb, M.A., et al., Dissolved organic matter in natural waters, Environmental Science and Engineering (Subseries: Environmental Science), 2013

[42] USEPA, "Ambient Water Quality Criteria for Ammonia, 1999 Update, Environmental Protection, EPA-822-R99-014." United States Environmental Protection Agency (USEPA), 1999.

[43] R. Bhateria and D. Jain, "Water quality assessment of lake water: a review." Sustainable Water Resources and Management, vol. 2, pp. 161-173, 2016.

[44] M. S. Pollock, and M. G. Dube, "The effects of hypoxia on fishes : from ecological relevance to physiological effects." Environmental Reviews, vol. 15, pp. 1-14, 2007.

[45] Sánchez, M. F. Colmenarejo, J. Vicente, "Use of the water quality index and dissolved oxygen deficit as simple indicators of watersheds pollution." Ecological Indicators, vol. 7, pp. 31 